УДК $351: 316.3$

DOI https://doi.org/10.32689/2523-4625-2021-1(60)-5

\title{
Геннадій ДМИТРЕНКО
}

доктор економічних наук, професор, кафедра управління персоналом та економіки праці, ПрАТ «ВНЗ «Міжрегіональна Академія управління персоналом», вул. Фрометівська, 2, м. Київ, Україна, 03039

ORCID: 0000-0002-8211-5690

\section{Анатолій ЧАУСОВ}

кандидат технічних наук, доцент, кафедра економіки та управління персоналом, Національний Університет біотехнологій і природокористування, вул. Генерала Родімцева, 19, м. Київ, Україна, 03041 ORCID: 0000-0001-9232-2629

\section{Gennady DMITRENKO}

Doctor of Economics, Professor, Department of Personnel Management and Labor Economics, Interregional Academy of Personnel Management, 2 Frometivska str., Kyiv, Ukraine, 03039 ORCID: 0000-0002-8211-5690

\section{Anatoliy CHAUSOV}

Candidate of Technical Sciences, Associate Professor, Department of Economics and Personnel Management, National University of Life and Environmental Sciences of Ukraine, 19 Henerala Rodimtseva str., Kyiv, Ukraine, 03041

ORCID: 0000-0001-9232-2629

\section{ШЛЯХИ ПОГЛИБЛЕННЯ РАЦІОНАЛЬНОСТІ СИСТЕМИ ПУБЛІЧНОГО УПРАВЛІННЯ ЯК СКЛАДОВОЇ СОЦІАЛЬНОГО УПРАВЛІННЯ WAYS OF DEEPENING THE RATIONALITY OF THE PUBLIC MANAGEMENT SYSTEM AS A COMPONENT OF SOCIAL GOVERNANCE}

Визначено актуальність проблеми низького рівня громадянської самодостатності українського суспільства, шо не дозволило сформувати рачіональну діяльність державної влади. Розкрито сутність раціонального управління як на рівні державного управління так $і$ на рівні будь-якої організації. Визначаються фундаментальні помилки державного управління в Україні за останні 30 років, представлено їх наслідки.

Раціональне державне управління розглядається як збалансоване управління в певних межах між необхідністю задоволення потреб в існуванні изіє̈ держави та задоволенням потреб ї̈ громадян через сприяння підвищенню якості їх життя у всіх сферах життєдіяльності.

Фрагментарно розкрито метод визначення якості життя громадян певних територій за допомогою сочіологічної системоутворюючої технології «Цифрове Віче». Завдяки впровадженню даної сочіологічної технології з'явиться можливість визначати пріоритетні проблеми певних територіальних громад та вирішувати їх в першу чергу для зниження в суспільстві рівня сочіальної напруги.

Ключові слова: раціональне державне управління, раціонального управління, соціальною системою, технологї̈ сочіального управління, сочіологічної системоутворюючої технологї та ін.

The paper devoted to the definition of the actual problem of the low level of civil self-sufficiency of the Ukrainian society, which did not allow to form rational activity of the state authorities.

The main purpose of the article is to consider the ways how to improve the rationality of social management system in Ukraine.

The quintessence of rational management both at the level of public administration and at the level of any organization is revealed. The fundamental mistakes of public administration in Ukraine for the last 30 years are determined and their consequences are presented.

Rational public administration is realized as a balance of management within certain limits between the existence of this state and the necessity to satisfy the essentials of its citizens via improving the quality of their lives in all spheres of life.

The most common technologies of social management are distinguished: linear; branched; by deviations; according to the situation; for results; by goals; search engine management.

Stages of the rationality improvement of the social management system are presented. It is proved that rational management is based on a sequence of stages of strategic management, which includes a strong definition of the 
final socially useful results. The classic principles of rational management of the organization as a social system in which all working components interact with each other as a team in order to obtain socially useful results of economic, social and environmental character. It is determined that a key socially useful result of the government activity should be indicators of the citizens' life quality.

The method of citizens'life quality determining on certain territories with the help of sociological system-forming technology "Digital Viche" is partially observed. This technology is able to provide feedback (from community to government) in the public administration system. This will enable the management elite to balance the interests of citizens and government within certain limits of rational public administration. Through the introduction of this sociological technology, it will be possible to identify problems priority of certain territorial communities and solve them primarily to reduce the level of social tension in society.

Key words: rational public administration, rational management, social system, technologies of social management, sociological system-forming technology, etc.

Постановка проблеми. За незначний історичний період (трохи більше 30 років), в процесі становлення своєї незалежності, Україна поступово опинилася на задвірках Європи як в економічному, соціальному, так і політичному аспектах. По факту Україна наразі займає останнє місто в Європі за головним економічним показником ВВП на душу населення та в числі перших місць - за корупцією, яка охопила всі сфери організації суспільства (політичну, економічну, соціальну, культурну, освітню), має гігантські борги перед міжнародними фінансовими установами (МВФ, ЄБРР та ін.), стратегічні проблеми з втручанням у внутрішні справи країни зовнішніх сил, а також величезні проблеми соціального характеру. Це стосується, в першу чергу, проблеми внутрішнього критичного роз'єднання населення країни (формування агресивної атмосфери політичних та соціальних відносин між людьми), а головне масового від’їзду мільйонів мешканців України за кордон в пошуках самореалізації.

Дана катастрофічна ситуація відбулась в Україні, яка до проголошення своєї незалежності визнавалась «райським куточком» авторитарної радянської системи завдяки потужному природному (тільки при певному дефіциті нафти та газу), промисловому, науковому і трудовому потенціалам, які поступово були втрачені впродовж останніх 30 років.

Це однозначно вказує на фундаментальні помилки в контексті раціонального державного управління в Україні, яка історично не мала своєї державності впродовж багатьох століть. Саме низька громадянська самодостатність суспільства не дозволила сформувати раціональну діяльність влади у справах державного масштабу.

Взагалі вивченню проблеми раціонального управління в контексті підвищення його ефективності (остання характеризується виміряними позитивними результатами, що порівняються 3 попередніми та плановими показниками чи стандартами) приділено багато уваги в науковій літературі. Але в даній статті акцентується увага лише на таких [1-11], які конкретно можуть бути використані для обгрунтування авторської позиції в розумінні раціональності саме в державному управлінні України.

Аналіз останніх досліджень і публікацій. В цьому сенсі в усвідомленні дійсної ролі людини в процесах демократичного державного управління на сучасному етапі становлення України, як незалежної держави, авторам особливо допомогли наукові твори Аджемоглу Дарон та Робін Джеймс $[1 ; 2]$. Мова йде про два потужних результати ї багаторічних досліджень розвитку самих різних країн на всіх континентах планети. Перший результат стосується висновку про те, що: «економічний успіх держав не залежить від культури, клімату або географічного положення... бідні країни бідують через вибір можновладців, які створюють бідність. Вони діють неправильно не через помилки або незнання, а навмисне» $[1$, с. 62]. Тобто додержуючись своїх егоцентричних інтересів.

Другий результат відноситься до висновку, що цивілізовані країни у своєму розвитку проходять «по вузькому коридору» балансування між діями влади та діями суспільства в умовах постійної боротьби і співпраці одночасно. Мова йде про те, що: «У цьому процесі... держава має служити своїм громадянам..., a владні еліти мусять навчитися жити в «кайданках», які на них вдягає суспільство» [2, с. 13].

Метою даної статті $\epsilon$ розгляд иляхів поглиблення раціональності системи соціального управління в Україні.

Виклад основного матеріалу починаємо із структуризації раціональності управління на два рівня: рівня держави в цілому і рівня будь-яких організацій (до яких відноситься також і органи державної влади).

В цьому контексті є сенс навести два приклади, що стосується нераціонального управління на рівні держави.

В першому випадку мова йде про входження України в ринкову економіку, коли ще за два роки до проголошення незалежності був прийнятий закон про «Кооперацію» для вирішення проблеми дефіциту широкого 
набору споживчих товарів, який створила економіка за радянських часів. На той час за наміром тодішньої влади була вивільнена підприємницька синергія активних людей, яка повинна була ліквідувати величезний дефіцит продуктових та промислових товарів широкого попиту. Але цього не сталося, тому що навмисно були зроблені дві помилки. Саме через них великий дефіцит товарів не зник, а виникла тотальна спекуляція вже виготовленими товарами і потужне збагачення одних (маючих безпосереднє відношення до влади) за рахунок інших - більшості громадян, споживачів цих товарів.

Перша помилка полягала у тому, що у Законі про «Кооперацію» було регламентовано тільки виробничі кооперативи, а не будь-які інші, включаючи посередницькі організації. Друга помилка полягала в неузгодженості дій влади з комерційними банками, які надавали позики за надто високі відсотки на досить короткий термін - до одного року, і це в той саме час коли вкрай необхідні були кредити мінімум на 3-5 років під невеликі відсотки для створення та розвитку сучасного виробництва.

У другому випадку мова йде про раціональне управління на державному рівні. Прикладом може слугувати ситуація 3 втратою Україною свого трудового потенціалу через масову еміграцію і виникнення великого прошарку заробітчан. Це було наслідком як об'єктивних факторів - переструктурування економіки на ринкові відносини, так і суб' єктивних неспроможності влади стратегічно та раціонального реагувати на зміни світового ринку.

Тому концентрація зусиль влади на той час відбулась в напряму самого раціонального на iї думку виходу із ситуації - забезпечення прав громадян вільно виїжджати і повертатися до України. Зокрема, був прийнятий закон України «Про порядок виїзду з України і в"їзду громадян України» (від 21.01.1994р.). Більше того, через три роки був зафіксований Указ президента України «Про основні напрями соціальної політики на 1997-2000 роки» (від 18.10 .1997 р. №1167). Там вперше було наведено твердження про те, що Україна є експортером робочої сили, а тому потребує активної державної політики в сфері соціального захисту працівників-мігрантів.

Отже, раціональність такої діяльності влади у цьому напрямі на той час продиктовано саме наміром мінімізувати ризик уникнення соціальних потрясінь в крайні замість турботи про кращу долю своїх громадян.

Але треба усвідомити той факт, що взагалі раціональність державного управління бере свій початок з раціонального управління організаціями як соціальними системами до яких відносяться і органи влади. Тому необхідно, в першу чергу, звернутися до теорії соціального управління і розглянути ії більш уважно, в тому числі з позиції іï практичного застосування через відповідні соціальні технології.

Технології соціального управління $є$ способом організації та упорядкування доцільної практичної діяльності людей, сукупність засобів, спрямованих на визначення або перетворення (зміна стану) соціального об'єкта та досягнення заданого результату. Використання соціальних технологій - це головний ресурс, що дозволяє знизити витрати на управління, збільшити ефективність управлінського впливу та його значення у житті суспільства [6, с. 55]. Технологія соціального управління - це сукупність послідовних операцій, що здійснюються людьми, процедур цілеспрямованого впливу та реалізації намічених планів (програм, проєктів), отримання оптимально-соціального та суспільно-корисного результату [7, с. 32]. Процедура - це набір дій, за допомогою яких відбувається керування процесом. Операція - безпосередня дія, шлях вирішення певного завдання у межах відповідної процедури [6; 7].

Сутність формування соціальної технології полягає у заздалегідь продуманих управлінських діях ініціатора, заснованих на вимогах до кінцевого результату. Вимоги враховують особливості властивостей виконавця, його поведінку і дії як особистості з певними соціально-економічними поглядами.

Теорія соціального управління дозволяє виділити наступні сім найбільш поширених технологій соціального управління [6; 7].

1. Лінійна технологія управління характеризується суворою послідовністю окремих робіт i операцій за принципом наступності, послідовності у відповідністю з розробленим планом. Вона використовується в типових випадках 3 достатньою визначеністю ситуації і кінцевої мети (звичайно при виконанні стандартних робіт, наприклад, в транспортній галузі).

2. Розгалужена технологія управління використовується тоді, коли неможливо точно оцінити ситуацію, виділити ключову проблему i намітити однозначно мету. Бажаний результат досягається на засадах сукупності рішень, розроблених паралельно, але за декількома напрямами, або одного, який має багатоаспектний характер. Звичайно така технологія має місце у сфері наукових досліджень.

3. Технологія управління за відхиленнями виникає на попередній фазі процесу, виходить 3 того, що частково останні зовсім не потре- 
бують корегування, частково їх подолання можливо силами самих виконавців, і тільки у разі їх значної кількості потребує втручання керівника. Такий підхід дозволяє не відволікати керівника на дрібниці та дати йому можливість зосередитись на управлінському процесі, тому що його втручання потребує великих витрат часу і засобів на створення нормативної бази, спостереження і аналізу відхилень, що спричиняє формалізацію i бюрократизацію управління.

4. Технологія управління за ситуацією застосовується в умовах великої невизначеності. Вона походить 3 існуючих обставин i використовує адекватні їм методи. Фази управлінського процесу часто незалежні один від одного, тому менеджер приймає оперативні рішення на основі постійного спостереження і аналізу змін у зовнішньому і внутрішньому середовищі організації.

5. Технологія управління за результатами полягає в тому, що при відсутності достатньої визначеності ситуації і розпливчатості кінцевої мети вона орієнтована на кінцеві результати. Дана технологія заснована на використанні потенціалу колективу, нових методів та технік управління. Ї̈̈застосовують, наприклад, в управлінні військами у бойових умовах.

6. Технологія управління за иілями близька до попередньої, але орієнтована на контроль і стимулювання досягнення не офіційних завдань, а особистих цілей, сформульованих в спеціальному документі.

7. Технологія пошукового управління виходить 3 повної ясності задач, але у випадку, коли неможливо точно оцінити ситуацію. Тоді рішення, відштовхуючись від мети, розробляються в зворотній послідовності фаз і коригуються по ситуації. Також даний тип управлінського процесу має місце при розробці довгострокового рішення в умовах високої невизначеності.

Структура об'єкта управління, його соціальна природа визначають побудову суб'єкта управління і структуру управлінських відносин, які виникають при цьому. Суб'єктами управлінських відносин стають усі співучасники управління незалежно від їх місця в структурі соціальної управляючої системи. Основними видами управлінських відносин $\epsilon$ відносини централізму і самостійності, субординації і координації, керівництва i підпорядкованості, відповідальності, конкурентоздатності, змагання та ін. Окремі види управлінських відносин органічно поєднані між собою і тільки в сукупності забезпечують функціонування i розвиток соціального управління.
Технології соціального управління забезпечують вибір способів впливу суб'єктів соціальної політики і соціального управління на об'єкт. Але динаміка життя потребує модернізації існуючих або розроблення нових технологій соціального управління, адекватних сучасним соціальним проблемам. Підвищенню якості i ефективності прийняття управлінських рішень сприяє створення професійної команди виконавців. Команда виконавців - це спеціально відібрана група фахових спеціалістів для об'єднання зусиль, спрямованих на розв'язання проблемної ситуації або спільне виконання важливого завдання. Керівник має бути не тільки організатором, але і лідером ефективної роботи команди виконавців.

Принципи і правила створення команди виконавців, методи роботи такої команди визначаються конкретним завданням, для вирішення якого зусилля всіх учасників команди повинні бути спрямовані на досягнення мети.

Перед застосуванням методів організації командної роботи необхідно чітко визначити цілі і завдання проблеми, які структурні одиниці будуть задіяні у роботі команди, які ролі i характеристики якостей $\epsilon$ у кожного з учасників команди. В системі державного управління можна застосовувати наступні методи організації командної роботи:

- метод експертних оцінок;

- метод «мозкового штурму»;

- метод чотирьох функцій менеджменту (I. Адізеса) [3].

При використанні методу експертних оцінок, учасники команди виконавців незалежно i анонімно формулюють свою думку щодо вирішення проблеми, надаючи відповідні оцінки. Узагальнення та прийняття рішень здійснює керівник. Зведені дані за усередненою оцінкою експертів подаються на розгляд кожному учаснику команди виконавців для 3'ясування причин відхилення оцінок. Тому процедура може бути повторена до досягнення повного консенсусу.

Метод «мозкового штурму» полягає у виявлені нових, запропонованих учасниками команди виконавців варіантів рішень конкретної проблеми. Відбувається генерація ідей щодо розв'язання проблемної ситуації, їх публічне обговорення щодо взаємоузгодження позиції. Метод чотирьох функцій менеджменту I. Адізеса [3] побудований на реалізації:

- функції отримання результату (Р);

- адміністративної функції (А);

- функції підприємництва (Е);

- функції інтеграції (I). 
Кожна функція позначається літерою, яка відповідає початку ії назви англійською мовою:

1. Producing results - утворення результатів, заради яких існує дана організація і які визначають ії результативність.

2. Administering - адміністрування, яке забезпечує ефективність управління.

3. Entrepreneuring - підприємництво, яке забезпечує ефективність використання ресурсів, раціональну організацію.

4. Integrating - інтеграція, об'єднання, елементів організації для забезпечення ії життєздатності в довгостроковій перспективі.

I. Адізес стверджує, якщо зневажати хоча 6 однією функцією 3 вказаних чотирьох, то неможливо забезпечити довгостроковий успіх організації, навіть якщо в короткостроковому аспекті вона буде демонструвати великі результати.

Визначаючи складність управлінської роботи Пітер Друкер наголошував: «Для рішення задач, які стоять перед вищим менеджментом потрібніпринаймні чотири типи людей: «Людина мислі», «Людина справи», «Людина народу» і «Людина переднього краю» [5].

При цьому П. Друкер визнає і те, що люди, які поєднують в собі всі чотири стилі, практично не зустрічаються. Державне управління на всіх рівнях надто складний процес, щоб з ним змогла впоратися одна людина. Відповідно окремі функції повинні виконувати різні люди. Щоб успішно управляти, необхідно зібрати разом керівників з різними підходами і різним мисленням (стратегічним, аналітичним, соціальним та ін.). Функції отримання результатів, наприклад, адміністратора, підприємця (як генератора ідей) та інтегратора повинна виконувати взаємодоповнююча команда виконавців.

Взаємодоповнююча команда - це команда, члени якої дотримуються різних підходів, а не копіюють один одного. Вони допускають різницю стилів і поглядів, урівноважують природну тенденційність підходів один одного.

Лідер має бездоганно виконувати одну з управлінських функцій, але при цьому бути неперевершеним інтегратором.

Було б доречно закінчити розгляд використання командної роботи в державному управлінні одним з висловів I. Адізеса: «Ми потрібні один одному не всупереч, а завдяки нашим різницям. Саме вони дозволяють подружньому союзу, компанії або суспільству залишатись здоровими в короткостроковому аспекті і довгостроковій перспективі» [3].

В сучасному світі можна знайти багато спільний питань, проблем, методів в різних галузях науки. Це стосується і методів управ- ління, які використовуються в технічних, соціальних, біологічних, хімічних і в багатьох інших системах. Широке використання систем автоматичного управління в енергетиці, авіації, космонавтиці, в транспортній галузі та різних виробництвах дозволило сформувати всебічні методи аналізу і синтезу систем управління. Слід відмітити, що деякі методи управління можна вважати спорідненими для різних галузей виробництва та суспільства. Це дає можливість використовувати в управлінні соціальними об'єктами окремі положення і підходи 3 теорії управління технічними об' єктами.

Розвиток методів дослідження систем автоматичного управління в авіації і космонавтиці дозволило розробити принципи раціонального управління, які можуть бути корисні також для соціальних об'єктів. Вони були сформульовані Куліком А. С. [8]. Їх головна відмінність від інших відомих принципів управління полягає у впровадженні принципу управління на основі діагнозу. Формування діагнозу здійснюється блоком діагностування, що дозволяє виявити дестабілізуючий вплив, ідентифікувати і локалізувати його, а потім відновити працездатність всієї системи. Раціональне управління формується на підставі поєднання аналітичних засобів дослідження, моделювання, а також макетних і експериментальних досліджень. Таким чином, система раціонального управління використовує діагноз усувних причин дестабілізуючих впливів. Це дозволяе не чекати змін вихідних параметрів об'єкта, а вдосконалювати систему заздалегідь.

Раціональне управління соціальним об'єктом відповідає теорії стратегічного управління будь-якими соціальними системами і складається із наступних етапів:

1) формулювання місії організації в залежності від профілю і масштабу іiі діяльності (в тому числі органів влади на різних рівнях);

2) визначення основних кінцевих цілей діяльності організації;

3) визначення засобів, які забезпечують досягнення цілей за певний період, включаючи фінансові, матеріально-технічні i паливно-енергетичні ресурси;

4) вибір технології реалізації стратегії досягнення цілей завдяки системному управлінню персоналом;

5) чітке визначення одержаних суспільнокорисних кінцевих результатів економічного, соціального і економічного характеру.

Отже, необхідно звернути увагу на той факт, що раціональність в системі управління будь-яким соціальним об'єктом (організації 
різного профілю і масштабності діяльності) обумовлено орієнтацією діяльності всіх його складових на досягнення кінцевих результатів $[5 ; 10]$. Саме ця орієнтація всіх без виключення працівників, підрозділів, відділів на кінцеві результати діяльності організації надає цілісність цієї діяльності і можливість отримати найкращі кінцеві результати за рахунок одержання синергетичного ефекту.

В даному контексті особливий інтерес представляють собою ключові структури державного управління - органи законодавчої і виконавчої влади на мікро (місцевому), мезо (регіональному) і макро (національному) рівнях. Мова йде про визначення чітких кінцевих результатів їх діяльності, пов'язаних iз якісним задоволенням потреб громадян держави вцілому.

Це $\epsilon$ основоположною проблемою державного управління в Україні, яка історично впродовж багатьох століть не мала своєї державності, та ще й була штучно поділеною на дві культури - Західну і Східну (що продовжує роз'єднувати сучасне суспільство країни).

Тому наріжним стрижнем поглиблення раціональності державного управління $\epsilon$ визначення стратегії розвитку України в тому «вузькому коридорі», що забезпечує одночасно і задоволення потреб держави в їі існуванні та розвитку, і задоволення потреб кожного громадянина як особистості і головної продуктивної сили суспільства.

Дійсно, структурам влади необхідно раціонально вирішувати одночасно дві групи стратегічних завдань, які виникають «ззовні» (від вищестоящих інстанцій) і внутрішньо (безпосередньо від громади). Цивілізовані країни знаходять свій «вузький коридор» національного управління через діяльність структур влади на основі демократії $\mathrm{i}$ розвиненого громадянського суспільства. Саме суспільство диктує владі орієнтири, що пов'язані із якісним задоволенням потреб громадян, які мешкають на певних територіях. В Україні суспільство в цьому напрямі ще не розвинене.

Тому, на думку авторів, на сьогодні необхідно сконцентруватися на визначенні чітких кінцевих результатів, які конкретизували брозмитий орієнтир влади на підвищення добробуту народу. Наприклад, шляхом його інтерпретації у вигляді цифрових показників якості життя громадян сіл, селищ, міст, що мешкають у відповідних територіальних громадах.

Якість життя громадян (ЯЖГ) - це найбільш глибокий показник рівня задоволення потреб людини у всіх сферах іiі життєдіяльності (починаючи 3 трудової і завершуючи особистісною), який демонструє те, як кон- кретній людині дійсно живеться в цій країни. Він є суб'єктивним показником, але легко може об'єктивізуватися, щоб стати реальним індикатором. А головне те, що він стає одночасно як індикатором раціональності державного управління, так і оцінкою ефективності діяльності структур влади. При цьому на всіх його рівнях, починаючи з місцевого і завершуючи національним, через середні індекси сукупності індикаторів (показників ЯЖГ) територіальних громад сіл, селищ, міст, районів, областей, країни вцілому.

Технологія визначення індикаторів якості життя громадян певних територій має стати унікальним інструментом формування громадянського суспільства в Україні, коли всі громадяни будуть мати можливість приймати участь в оцінці кінцевих результатів діяльності структур влади. Здійснити це можливо шляхом щорічного соціологічного опитування населення (на кшталт місцевих референдумів) за допомогою «розумних» цифрових анкет. Детальне обгрунтування і опис цієї унікальної технології, яка одержала назву «Цифрове Віче», висвітлено в науково-публіцистичний літературі $[4 ; 11]$.

Соціологічна технологія «Цифрове Віче» здатна налагодити зворотній зв'язок (від громади) в системі державного управління, що надасть можливість управлінській еліті навчитись жити в умовах, які вимагає від них громадянське суспільство у «вузькому коридорі» раціонального державного управління.

Висновки. Таким чином, соціологічна системоутворююча технологія «Цифрове Віче» своєрідно завершує комплекс з уже відомих сучасних цифрових інструментів громадянського суспільства, пов'язаних з відображенням на електронних сайтах владних структур ïх замислів і рішень, створення при них Громадських рад та інше.

В цьому контексті $є$ сенс навести ще одну відому тезу великого прихильника раціонального державного управління Лі Куан Ю: «Постійний контакт із народом необхідно підтримувати не тільки для того, щоб знати його проблеми і негаразди, а щоб керувати ним і організувати, прищеплювати громадські якості, які будуть корисними для розбудови суспільства $[9$, с. 140$]$.

Це більш ніж актуально для сучасної України, тому що саме соціологічна системоутворююча технологія «Цифрове Віче» нарешті вирішуе проблему низької самодостатності громадян, які й досі відчувають себе об'єктом маніпулювання політиків. Технологія «Цифрове Віче» призначена здійснити великий внесок в об'єднання роз'єднаних громад України. 


\section{Література:}

1. Аджемоглу Дарон, Робінсон Джеймс. Вузький коридор. Держави, суспільства і доля свободи. Пер.з англ. Геннадій Шпак. К. : Наш формат, 2020. 520 с.

2. Аджемоглу Д., Робінсон Д. Чому нації занепадають походження влади, багатства та бідності. 2-ге вид., випр. / Пер. $з$ англ. і наук. ред. О. Дем’янчук. К. : Наш формат, 2017. 440 с.

3. Адизес I. Стилі менеджменту - ефективне і неефективне / Іцхак Калдерон Адезес; пер. 3 англ. 2-е вид. М. : Альпина Паблишер, 2012. 198 с.

4. Дмитренко Г. А., Головач Н. В., Білінський Т. В., Головач Д. М. Як уникнути соціальних потрясінь. Цифрове «Віче». Науково-публіцистичне видання / Під. заг. ред. Г. А. Дмитренка. К. : ДКС-Центр, 2021. $277 \mathrm{c}$

5. Друкер Петер. Управление, нанацеленное на результати. Пер. с англ. / Петер Ф. Друкер. М. : Техн. Школа бізнеса, 1994. 220 c.

6. Катвалюк А. Л. Соціальні технології. Тернополь : Економічна думка, 2001. 284 с.

7. Крушевський А. В. Системне дослідження економічних об’єктів. К. : ІПК «Укрприрода», 1999. $167 \mathrm{c}$.

8. Кулик А. С. Елементи теорії раціонального управління об’єктами. Х. : Нац. аерокосм. Ун-т ім. Н. Е. Жуковського «XAI», 2016. 255 с.

9. Лі Куан Ю. Роздуми великого лідера про майбутнє Китаю, США та світу / Г. Елісон, Р. Д. Блеквілл, Е. Вайн : пер. $з$ англ. О. Лобастової. К. : Вид група КМ-Букс, 2018. 224 с.

10. Санталайнен Т. Управление по результатам. Пер. сфинск. / Т. Санталайнен, Е. Воутилайнен и др. М. : Прогресс. 1993. 266 с.

11. Системна модернізація державного управління в Україні: гуманістичний контекст: кол. монографія / Братусь Г.А., Головач Н.В., Дмитренко Г.А., Дорошенко Л.С., Згалат-Лозинська Л.О. та ін. / За заг. ред. Г. А. Дмитренка. К. : ДКС-Центр, 2020. 512 с.

\section{References:}

1. Adzhemohlu Daron, Robinson Dzheims. (2020) Vuzkyi korydor. Derzhavy, suspilstva i dolia svobody [Narrow corridor. States, societies and the fate of freedom]. K. : Nash format. [in Ukrainian].

2. Adzhemoglu D., Robinson D. (2017) Chomu natsii zanepadaiut pokhodzhennia vlady, bahatstva ta bidnosti [Why nations are declining origins of power, wealth and poverty]. K.: Nash format. [in Ukrainian].

3. Adyzes I. (2012) Styli menedzhmentu - efektyvne i neefektyvne [Management styles are effective and ineffective]. M. : Alpyna Pablysher, [in Ukrainian].

4. Dmytrenko H. A., Holovach N. V., Bilinskyi T. V., Holovach D. M. (2021) Yak unyknuty sotsialnykh potriasin. Tsyfrove «Viche» [How to avoid social upheavals. Digital Viche]. K.: DKS-Tsentr. [in Ukrainian].

5. Druker Peter. (1994) Upravlenie, nanaczelennoe na rezul'tati [Results driven management]. M. : Tekhn. Shkola bi`znesa. [in Russian].

6. Katvaliuk A. L. (2001) Sotsialni tekhnolohii. [Social technologies]. Ternopol: Ekonomichna dumka. [in Ukrainian].

7. Krushevskyi A. V. (1999) Systemne doslidzhennia ekonomichnykh obiektiv [Systematic research of economic objects]. K. : IPK «Ukrpryroda». [in Ukrainian].

8. Kulyk A. S. (2016) Elementy teorii ratsionalnoho upravlinnia obiektamy [Elements of the theory of rational object management]. Kh.: Nats. aerokosm. Un-t im. N. E. Zhukovskoho «KhAI». [in Ukrainian].

9. Li Kuan Yu. (2018) Rozdumy velykoho lidera pro maibutnie Kytaiu, SShA ta svitu [The Great Leader's Reflections on the Future of China, the United States and the world]. K. : Vyd hrupa KM-Buks. [in Ukrainian].

10. Santalajnen T. (1993) Upravlenie po rezultatam [Results management]. M. : Progress. [in Russian].

11. Dmytrenko H. A. (2020) Systemna modernizatsiia derzhavnoho upravlinnia v Ukraini [System modernization of public administration in Ukraine]. Kyiv: DSK-Center. [in Ukrainian]. 